\title{
UN body will assess ecosystems and biodiversity
}

The United Nations is setting up a body to monitor global ecology modelled on its influential climate panel. Last week, representatives from 85 countries gathered in Busan, South Korea, to approve the formation of the Intergovernmental Science-Policy Platform on Biodiversity and Ecosystem Services (IPBES), which will operate much like the Intergovernmental Panel on Climate Change.

According to the document hammered out on 11 June, the IPBES will

"Governments wanted to be reassured that it would be lean and mean and streamlined." for humanity. Assessments will take place from global to sub-regional scales.

The IPBES will help to train environmental scientists in the developing world, both with a budget of its own and by alerting funders to gaps in global expertise. The organization will also identify gaps in research and highlight tools - such as models - for policy-makers looking to apply a scientific approach to decisions on issues such as land management.

Negotiations in Busan stretched late into the night as delegates debated the scope of the IPBES and how it would be funded. A key concern among developed countries was that the body should "not become a huge bureaucracy", says Nick Nuttall, a spokesman for the United Nations Environment Programme. "Governments wanted to be reassured that it would be lean and mean and streamlined."
Among the governments that assented to the IPBES's creation were the European Union, the United States and Brazil. This autumn the plan will come before the general assembly of the United Nations for official approval, which those involved say is a virtual certainty.

Anne Larigauderie, executive director of Paris-based Diversitas, a facilitator for biodiversity science, says that the IPBES could turn the "fragmented" field of biodiversity research into a more coordinated "common enterprise" that will lead to better models of future biodiversity changes.

Emma Marris

For a longer version of this story, see go.nature. com/cyOPX2.

Correction

The Editorial 'Mouse megascience' (Nature 465, 526 ; 2010) wrongly stated that the estimated cost of phenotyping 4,000 mouse genes is $\$ 900$ million; that is actually the estimated cost for phenotyping all 20,000 mouse genes. is declining and what the implications of extinctions and ecosystem change might be

MOSQUITO SPRAY HITS

House martins may be affected by insect control. go.nature.com/mUUpVS

ecosystems outputs, such as fresh water, humankind. These assessments, based on reviews of the scientific literature, will answer questions about how much biodiversity 